\title{
Shifting Priorities, Attitudes, and Institutional Change: \\ Reflections on UNHCR at the Crossroads
}

\author{
BRIAN GORLICK
}

\begin{abstract}
The international debate on refugee issues is in flux and has been influenced by a number of factors including post-cold war disinterest in refugees, the media, extraordinary humanitarian crises, and shifting attitudes among policy makers and the public. Over the last decade in particular, the Office of the United Nations High Commissioner for Refugees (UNHCR) has been given the task of providing protection and relief in large-scale humanitarian operations, some of which are unprecedented in size, level of conflict, and categories of persons provided assistance. In the new millennium and under new leadership, will UNHCR get back to "the basics of protection," or will it continue to be asked to respond to humanitarian crises in the absence of other action by the international community? These are serious policy questions facing the Office.
\end{abstract}

\section{Résumé}

Le débat international sur les questions touchant aux réfugiés est en état d'effervescence. Il a été influencé par un certain nombre de facteurs dont: le manque d'intérêt général, dans la période suivant la fin de la guerre froide, pour des questions concernant les réfugiés, le rôle joué par les médias, les crises humanitaires qui ont pris des proportions extraordinaires et les attitudes qui ont changé tant chez les dirigeants politiques que parmi le grand public. Au cours de la dernière décennie en particulier, le Haut Commissariat s'est vu sollicité pour fournir aide et protection dans des opérations humanitaires de grande ampleur, certains desquelles n'avaient pas de pareil en terme d'envergure, niveau du conflit et catégories de personnes qui ont reçu de l'aide. Au début d'un millénaire et sous une nouvelle direction, la HCR doit faire face à des d'importantes décisions politiques: Retournera-t-elle à sa mission première qui est de fournir la protection de base aux réfugiés ou, en l'absence d'autres initiatives par la communauté internationale, continuera-t-elle à être sollicitée pour prendre en charge diverses crises humanitaires?

$$
\curvearrowleft
$$

In the mid-1970s, about 80 million people-roughly 1.5 per cent of the world's population-were living outside the country of their birth. The figure is now closer to 150 million, according to the International Organisation for Migration. It seems implausibly small, but the extent of human movement across borders is hard to monitor-and the figures are a mystery for those of us who have no idea how many people move in and out of our neighbourhoods in a single day, or a year, or the course of a decade... Refugees are not necessarily poor, but by the time they have reached safety, the human trafficking organisations on which they depend have eaten up much of their capital. In the course of the excruciating journeys, mental and physical resources are also expended-some of them non-renewable.

- Jeremy Harding

"The Uninvited: Refugees at the Rich Man's Gate"

$\mathrm{T}$ he future of the international system of refugee protection is the subject of much debate. Increased numbers of asylum seekers and people on the move, largely from countries in the South, have given rise to calls from many Northern politicians and policy-makers for increased controls. In some instances, countries with strong 
traditions of receiving refugees and giving shape to the international regime of refugee protection are calling for a review of the very system they helped create. Despite the continuing value of international refugee law and asylum practices, many feel the system is not working and that international refugee law in particular cannot provide states with the means necessary to control irregular migration, while helping to identify those who deserve international protection.

Echoing these sentiments, the British home secretary recently proclaimed that the 1951 Refugee Convention is "no longer working as its framers intended," and that "the environment in which it is applied today is one that has changed almost out of all recognition from that of 1951." In brief, he added, "numbers of asylum seekers have vastly increased." While not offering a ready formula for fixing the international system, the home secretary did identify the need to rectify the severe imbalance between the costs of processing asylum applications in developed countries and of making conditions in the regions of origin better for refugees. ${ }^{1}$ Such initiatives, the home secretary proposed, "will reduce the pressure on refugees to travel further afield in search of protection." He went on to suggest that the EU set up a program "under which an agreed number of refugees-and possibly others in need of protection-would be identified in their own regions and brought to the EU for resettlement." The advantages of an enhanced resettlement scheme would be to reduce overall expenses to states, while providing more orderly identification and reception of individuals deserving refugee protection based on agreed criteria. Last, the home secretary suggested that "an EU or internationally agreed list of safe countries or groups from which asylum applications would be ruled inadmissible or considered under a greatly accelerated process" would help reduce the phenomenon of "asylum shopping."

In fact, it is a refrain among some states not party to the international refugee instruments that the 1951 Refugee Convention and 1967 Protocol are outdated and Eurocentric and thus of limited relevance in dealing with refugee problems in less-developed countries. Accordingly, these countries argue, there is little value in becoming party to the international refugee instruments. Such views, which have been applauded by some, were expressed in a speech by the former Indian Permanent Representative to the UN at the Forty-eighth Session of the UNHCR Executive Committee:

International refugee law is currently in a state of flux and it is evident that many of the provisions of the [1951 Refugee] Convention, particularly those which provide for individualised status determination and social security have little rel- evance to the circumstances of developing countries today who are mainly confronted with mass and mixed inflows. Moreover, the signing of the Convention is unlikely to improve in any practical manner the actual protection which has always been enjoyed and continues to be enjoyed by refugees in India. We therefore believe that the time has come for a fundamental reformulation of international refugee law to take into account the present day realities ... [I]t has to be recognised that refugees and mass movements are first and foremost a 'developing country' problem and that the biggest 'donors' are in reality developing countries who put at risk their fragile environment, economy and society to provide refuge to millions. An international system which does not address these concerns adequately cannot be sustained in the long run ...

The underlying theme in these comments is concern about increasing numbers of refugees and asylum seekers and the disproportionate burden on states. Related concerns about security, and the economic and environmental impact of involuntary movements of persons, also fuel the search for new systems and methods to deal with and contain refugees and unwanted migrants, as some would have it, beyond one's borders.

Over the last several years, many policy-makers have called for a re-examination of the international refugee instruments. Questioning the legal instruments and, in consequence, the basic principles of international refugee protection, has arisen because of shifts in the global perspective on refugee problems, particularly in the post-cold war era. The powerful role of media attention (or lack thereof), in addition to ideological shifts in refugee discourse, have also shifted international response to refugee outflows.

Adam Roberts has written that developments in the $1980 \mathrm{~s}$ and 1990s, "especially the increase in refugee numbers and the raising of barriers by states against inflows of immigrants," resulted in considerable changes "in the international handling of refugee issues." The "hardening of attitudes towards refugee influxes," coupled with intense media focus on select refugee crises, has led to "major political and military consequences." According to Roberts, such attention has contributed to the international communities' compulsion to take action, to (ideally, from a Western perspective) "tackle refugee issues in or near the country of origin." 3 The post-cold war attitude that refugees have limited value as political pawns also explains the reluctance of powerful governments to provide military forces in conflicts, and in the end that reluctance exacerbates refugee movements. Gil Loescher has argued that "governments feel compelled to respond to refugee disasters, especially those covered extensively by the media, and therefore are likely 
to task the UNHCR and other international agencies to provide relief aid." Loescher further suggests that "the provision of humanitarian assistance is financially and politically a relatively low risk option for governments because it satisfies the demands of both the media and public opinion for some kind of action to alleviate human suffering ... but it is also used by governments as an excuse for refusing to take more decisive forms of political and military intervention." 4

As part of this global shift in the North's response to refugee crises, UNHCR has been pressured to play an increasingly expanded role. With no other international organization specifically mandated to deal with humanitarian crises that result in forced movements of individuals, within countries of origin or across international borders, UNHCR is seen as the UN agency with the closest responsibility to put into operation and coordinate large-scale humanitarian response, regardless of whether the victims of such displacement would formally come under the mandate of the Office. ${ }^{5}$ The fact that UNHCR maintains an extensive field presence, and since the Gulf War has gained renewed prominence as the lead UN agency in coordinating large-scale humanitarian operations, has also changed the Office's perceived mandate and operational response.

During Sadako Ogata's ten-year service as High Commissioner for Refugees, the Office found itself in uncharted territory, which in some instances led to deployment of civilian staff into environments riddled with conflict, such as the former Yugoslavia or the former Zaire, or more recently West Timor. Difficulties associated with protecting Rwandan refugees in the former Zaire and UNHCR's role in the former Yugoslavia have also resulted in severe criticism from some quarters, and aspects of these operations have been considered to be a distortion of the Office's mandate and a failure of commitment to protection principles. It has even been argued that humanitarian relief activities offered in a climate of armed conflict inevitably confuse the mandates of respective un actors in the field, and in the extreme may result in perpetuation of the conflict rather than an expedited peace. ${ }^{6}$ Another legacy is that these operations, despite what is no doubt their considerable success in saving lives, will always be tragic reminders of the risks humanitarian workers are exposed to in order to relieve and protect civilian victims. ${ }^{7}$

Some commentators may argue that the evolution of UNHCR's mandate and operational priorities were inevitable as a result, in part, of the changing nature of conflicts and the dynamics of displacement. However, the fact cannot be ignored that the Office itself was willing to meet the demands of the international community. The correspond- ing increase in UNHCR's human and financial resources (with an annual budget almost exclusively reliant upon voluntary donations from a small number of developed states) from $\$ 69$ million in 1975 to a high of $\$ 1.4$ billion in 1996 and some $\$ 1$ billion in 1999; and the number of persons of concern to the Office jumping from 2.4 million in 1975 and some 23 million today, also blurred the categories of persons in need of international protection. Such rapid growth and unprecedented demands on the organization has not been without problems. The fact that during the height of the crises in the African Great Lakes region and the former Yugoslavia one quarter of UNHCR's annual budget went to these two operations alone is worth considering in the broader context of how limited resources are ear-marked and spent. ${ }^{8}$

The demands on UNHCR and other humanitarian actors in the last few years to become involved in no-win situations have been problematic and have required the Office to become engaged in debates and negotiations on international security. Although it is inevitable that UNHCR assumes this role, and although some have argued that UNHCR's work was never devoid of political implications, UNHCR and the refugee issues both have a prominence today different from when the Office was first established. ${ }^{9}$

Chimni argues that one consequence of increased involvement of the Un Security Council and NATO in refugee matters is that refugee protection will be "couched in the language of security." He identifies three outcomes of this development: (1) refugees' perceived threat to a host country's security may lead to reduced adherence to fundamental rights such as the principle of non-refoulement; (2) the use of the language of security may lead to justifying the use of force against a country of origin "even if, as was the case in Kosovo (and earlier in Iraq), the use of force actually accelerates refugee flows"; and (3) the language of security "invades the world of humanitarianism and starts to displace it."10

Chimni's critique and what has been offered by the analysis of international relations demonstrate that the development of linkages between managing refugee flows and concerns about international security have required de facto changes in UNHCR's mandate and practices. This, in turn, has resulted in the perception that new and exceptional responses to refugee problems must also be developed.

The only falsehood in such thinking, in this commentator's view, is that changes in the international communities' response to refugee crises have also been shaped in reaction to exceptional and often high-profile operations, as well as, in some instances, alarmist claims about increased numbers. ${ }^{11}$ In this context, what may be considered more 
traditional UNHCR operations geared towards facilitating asylum and securing basic protection and socio-economic rights for refugees, particularly in developing countries, have been largely ignored by the international media-and so, it seems, many academic commentators. Yet in the current climate, if a crisis is out of the eye of the media, funding and related difficulties commonly follow. The humanitarian funding crises for Afghan refugees is but one contemporary example. UNHCR should guard against the correlation between media attention and funding for refugee programs, and the resultant selectivity in the international response. Nonetheless, political expectations and precedents in operational responses, not to mention the development of "soft law" through the passage of countless resolutions in international forums, have gone far beyond extending the mandate of UNHCR to categories of persons whom it assists.

According to Roberts, UNHCR has been a victim of "force of circumstance" that cannot be wished away. In supporting this conclusion, Roberts cites the exceptional examples of northern Iraq, the former Yugoslavia, and Rwanda to explain UNHCR's pressured response to "prevent huge influxes [of refugees] to other countries, to try and feed and protect threatened people in their own countries, to arrange temporary rather than permanent asylum abroad, and to get those who have fled to return." ${ }^{12}$ At the end of the day, UNHCR may have been a victim of its own success. Whether UNHCR can or will take steps to guard against the reshaping of its protection mandate and operational response, or as some commentators have argued, return to "the basics of protection," are serious policy questions UNHCR will have to address.

A final issue that deserves attention when contemplating international refugee affairs is the impact of racism and xenophobia on popular culture in Western societies. Although it is difficult to establish that an increase in restrictive policies towards refugees are a direct result of purely racist attitudes, the rise of right-wing movements, which in many instances have had considerable influence on the political mainstream, is certainly cause for concern. This political dynamic is well summed up by Reg Whitaker:

Governments increasingly find themselves pressured from opposite directions. Civil libertarians and immigrant communities on the one side demand more generous policies and decry racism. Extreme right-wing xenophobic and nationalist movements on the other side demand more restrictive policies and assert the priority of the native born. Faced with this equation, most governments have opted to give more ground to the right, a decision perhaps dictated as much by the politicians' finely tuned sense of where more votes can be found than by burning racist convictions. The existence of racist influences on policy does not in itself demonstrate that policy is determined by racism. In the case of refugees, there are enough reasons to see why governments are becoming increasingly ungenerous, even obstructionist, without recourse to racism as a totalising explanation. ${ }^{13}$

The fact that many European countries, including ones with strong human-rights traditions such as the Nordic countries, have seen growing popularity of political parties that promote an anti-immigrant agenda, has had a negative effect on the domestic refugee debate. Sweden, for example, which can rightly pride itself alongside the other Nordics as being a strong supporter of UNHCR and global human rights issues, is grappling with its own extremist movements at home. Although Sweden's extremist movements have thus far been shunned by the political mainstream, they have had a disturbing impact on Swedish society in other ways. In 1999 the Swedish security police reported that 940 crimes had been committed by Swedish neo-Nazi groups. Many of these incidents involved violent assaults on immigrants but included the murder of two police officers and a well-known trade-union official who was shot after exposing a colleague as a neo-Nazi infiltrator. These murders were followed by serious threats and attacks on a number of others, including journalists and other individuals working on behalf of anti-racist campaigns or with immigrants and refugees. Many of these victims are now under police protection. Groups based in Sweden are also among the most active in Europe in producing and disseminating white power music and racist propaganda via the Internet. The police have reported that the core group of neo-Nazis in Sweden consists of 1,500 people, but they have several thousand sympathizers. Tougher action against offenders has been demanded by some politicians and the public, but many are reluctant to surrender to growing demands to ban neo-Nazi groups, because such restriction would conflict with laws and policies on freedom of expression.

Countering emerging extremism, in addition to the broader imperatives of maintaining the international system of refugee protection based on the rule of law and equitable burden sharing, are all serious challenges facing the international community and the new leadership of UNHCR. To meet these challenges will now, more than ever, require sound policies and practices on the asylum front that are grounded in a strong commitment to human rights. Support in the form of financial and other economic contributions, as well as inter-state cooperation and harmonization of practices to high protection standards, will also need 
to be put in place. The refugee problem is not getting any smaller or easier to deal with, nor will it go away. That the refugee problem would somehow come to an end is what states thought, or perhaps wished to think, when UNHCR was created some fifty years ago. Regrettably, they were sorely mistaken.

\section{Notes}

1. Hathaway draws a telling comparison of refugee burden sharing in Northern and Southern states: "Of the 26 states hosting at least one refugee per 100 citizens, 21 were among the world's poorest (i.e., they had a per capita income of less than $\$ 1000$ per year) ... The Refugee Convention speaks about the importance of sharing, but incorporates no mechanism to make it happen. Northern states each year spend at least $\$ 12$ billion to process the refugee claims of about $15 \%$ of the world's refugee population, yet contribute only $\$ 1-2$ billion to meet the needs of $85 \%$ of the world's refugees who are present in comparatively poor states ..." Keynote address, New Delhi Workshop on International Refugee Law, Indian Journal of International Law 39, no. 1 (January-March 1999), 11.

2. Speech by U.K. Home Secretary Jack Straw, to the Institute for Public Policy Research, London, February 6, 2001 (on file with the author).

3. Adam Roberts, "More Refugees, Less Asylum: A Regime in Transformation," Journal of Refugee Studies (JRS) 11, no. 4 (December 1998), 379 .

4. Gil Loescher, "The UNHCR and World Politics: State Interests vs. Institutional Autonomy” (paper prepared for an international conference, "Commemorating UNHCR at 50: Past, Present and Future of Refugee Assistance," Columbia University, New York, May 15-18, 2000), forthcoming in International Migration Review, spring 2001.

5. "Between 1991 and 1997 the Security Council made specific reference to UNHCR assuming a leading humanitarian role more than 30 times, in contrast to merely four times prior to $1991 \ldots$ In Kosovo, UNHCR worked in partnership with an overt party to a conflict even without the cover of a UN Resolution, so that 'its claim to be a neutral actor looked increasingly threadbare." B. S. Chimni, "Globalization, Humanitarianism and Refugee Protection," JRS 13, no. 3 (September 2000), 256.

6. See for example, S. Alex Cunliffe and Michael Pugh, "The Politicisation of UNHCR in the Former Yugoslavia," JRS 10, no. 2 (1997); Michael Barutciski, “The Reinforcement of Non-Admission Policies and the Subversion of UNHCR: Displacement and Internal Assistance in Bosnia-Herzegovina (1992-1994)," IJRL 8, no. 1/2 (1996); Bill Frelick, "Preventing Refugee Flows: Protection of Peril?" World Refugee Survey 1993, U.S. Committee for Refugees, Washington, DC. In a news article in Le Monde May 29, 1997, a representative of Médicins sans frontières Foundation targeted UNHCR for criticism as head of the UN's repatriation operation for Rwandese refugees from the former $\mathrm{Za}$ ire thus: "Instead of standing up for the right of asylum and security guarantees for refugees in Rwanda itself, [UNHCR] is undertaking this repatriation under international pressure.” The
MSF representative went on to criticize the international community's "understanding" of the Rwandan government whose representatives "are killing refugees by the thousands," and then posed the question, "Should UNHCR bring refugees back to the country of their oppressors in the name of humanitarianism?" Also see Edward N. Luttwak, "Give War a Chance," Foreign Affairs (July/August 1999), 36-44. For a counterview see Nicholas Morris, "Protection Dilemmas and UnHCR's Response: A Personal View from within UNHCR," IJRL 9, no. 3 (1997).

7. A press release from the Swedish Ministry for Foreign Affairs, March 29, 2001, on support for the UN Trust Fund for Security of un staff members notes, "The lack of security for un personnel has been highlighted on several occasions. Two serious incidents have occurred during the past week, one in the Democratic Republic of the Congo where an employee of UNHCR was killed, and one in Mogadishu in Somalia where a number of international relief workers for Doctors without Borders and the un were abducted and locally employed Somalis killed. Since 1992, some 200 civilian UN staff members have list their lives in the execution of their duty, and since 1994 some 240 have been held hostage or kidnapped. In addition, un personnel have been the victims of threats and assaults on many occasions, and humanitarian transport has been attacked."

8. It is perplexing to see certain refugee groups (Afghans in South Asia, for example) being largely without direct financial or social assistance from UNHCR, as a result of budgetary retrenchment. Before cuts were made in financial assistance to urbanbased Afghan refugees in India, for example, subsistence allowances were approximately us $\$ 1$ per refugee per day. However, in another part of the world, donors have provided funds to establish legal-aid resource centres for returnees who wish to get their homes back in Bosnia and Herzegovina. Resource allocation is often beyond UNHCR's control, when funds are earmarked by donor countries. Nevertheless, the result is unequal protection and assistance to certain groups of refugees. The Office has at times been the subject of strong criticism as a result of these operational imbalances.

9. The Statute of the Office of the UNHCR provides that "The work of the High Commissioner shall be of an entirely non-political character; it shall be humanitarian and social and shall related, as a rule, to groups and categories of refugees." General Assembly Resolution 428(v) of December 14, 1950, chapter 1, "General Provisions," para 2. The Preamble of the 1951 Refugee Convention also expresses a similar sentiment: "Expressing the wish that all states, recognising the social and humanitarian nature of the problem of refugees, will do everything within their power to prevent this problem from becoming a cause of tension between states." 189 United Nations Treaty Series 137, as updated by the 1967 Protocol relating to the Status of Refugees, January 31, 1967, 606 unTs 267.

See Mark Cutts, "Politics and Humanitarianism," Refugee Survey Quarterly 17, no. 1 (1998), who suggests, "rather than attempting to universalise the ICRC approach to humanitarian action, perhaps what is needed is for a clear distinction to be drawn between the different types of humanitarian organisations. On the one hand there are independent organisations 
which espouse neutrality, which seek to avoid politics, which focus on palliatives rather than solutions and mitigation rather than prevention, and which operate only on the basis of consent. On the other hand there are those organisations, including United Nations organisations such as UNHCR, which do not necessarily conform to any of these standards or philosophies. The United Nations is, after all, a political organisation, and one which has enforcement powers of its own."

10. Chimni, "Globalization, Humanitarianism and Refugee Protection," 252-3.

11. The perception that "vastly increased" numbers of asylum seekers and immigrants are invading Western Europe deserves further study. However, it is worth considering the following: Goodwin-Gill has suggested, "Numbers in and of themselves are not a problem. In the immediate aftermath of the First World War, Europe faced a refugee population of some 80o,ooo Russian refugees. They were soon joined by Assyrians, Armenians, Assyro-Chaldeans, Germans, Spaniards and others. At the end of the Spanish Civil War, France received some 400,00o refugees within a period of ten days. After the Second World War, Europe was a refuge, often temporary, to over 1.6 million refugees and displaced persons. Other regions in other times have coped with as many or more ..." "Editorial: Refugees and Security," IJRL 11, no. 1 (1999), 2.

In January 2001 the UNHCR Registration and Statistical Unit reported that provisional data provided by governments to UNHCR indicate that 452,000 asylum applications were submitted in twenty-five European countries in 2000, 4 per cent less than in 1999. In the fifteen EU countries, the number of applications rose slightly, from 387,000 in 1999 to almost 390,000 in 2000, with the U.K. receiving the largest number of asylum applications (approximately 97,900), followed by Germany $(78,800)$, and the Netherlands $(43,900)$. Slovenia received the largest number of asylum seekers in Europe during 2000, with 4.7 applications per 1,0oo inhabitants, followed by Belgium (4.2) and Ireland (2.9). The three main nationalities of asylum seekers in Europe remained unchanged compared to 1999: citizens from the Federal Republic of Yugoslavia (FRY) submitted the largest number of applications (42,300), followed by nationals from Iraq $(34,700)$ and from Afghanistan $(28,800)$. The number of Iranian applications more than doubled from 12,100 in 1999 to 27,100 in 2000 . Significant decreases were reported in the number of applications submitted by citizens from the FRY (64 per cent) and Somalia ( -26 per cent); The Economist, citing a United Nations Population Fund of 2000, noted, "In order to keep its working-age population stable between now and 2050, at current birth and death rates, Germany would need to import 487,00o migrants a year ... France would need 109,000, and the European Union as a whole 1.6 million. To keep the ratio of workers to pensioners steady, the flow would need to swell to 3.6 million a year in Germany, 1.8 million a year in France and a staggering 13.5 million a year in the Eu as a whole." (The Economist Mobile Edition, October 5, 2000); Finally, for an excellent article that debunks a number of common myths about global migration, see Demetrios Papademetriou, "Migration:
Think Again," Foreign Policy, winter 1997-8.

12. Roberts, "More Refugees, Less Asylum: A Regime in Transformation," 382.

13. Reg Whitaker, “Refugees: The Security Dimension," Citizenship Studies 2, no. 3 (1998), 429-30.

Brian Gorlick is a refugee law training officer, UNHCR Regional Office for the Baltic and Nordic Countries, Stockholm. The views expressed in this article are those of the author and do not necessarily reflect those of the United Nations or UNHCR. 